\title{
Canada to set up genome research centre in Toronto
}

\section{Soros foundation is defended against charges of spying} man genome research and molecular medicine will be built at the Samuel Lunenfeld Research Institute of Mount Sinai Hospital, Toronto, through government and industry grants totalling C $\$ 15.3$ million.

Bristol-Myers Squibb will provide C\$10.3 million over five years for molecular biology research at the centre, almost doubling the C\$5.75-million it gave to the institute in 1990 .

William Scott, a senior research vicepresident for the company, has made it clear that the federal government's recent expansion of patent protection was a factor in the company's decision to make the new award

The institute said that the company's contribution also helped to secure $\mathrm{C} \$ 5$ million in funding from the Canada/Ontario Infrastructure Works programme to build the centre, to be called the Centre for Human Genome Research and Molecular Medicine. Federal, provincial and local governments will each contribute one-third of the cost of the 25,000-square-foot laboratory.

The centre's research will focus on gaining an understanding of genetic factors responsible for human development and the molecular basis - - and perhaps the subsequent diagnosis and treatment - of such diseases as breast and prostate cancer, diabetes, asthma, birth defects, heart, bone and neurodegenerative diseases.

According to the institute, the centre will provide 150 full-time and permanent research positions and provide training in DNA and gene methodologies.

David Spurgeon
Montreal. Canada's largest centre for hu-

Moscow. Boris Saltykov, the Russian minister for science, last week came to the defence of the International Science Foundation (ISF) against charges that it is being used by the United States to spy on the activities of Russian scientists. Saltykov told a press conference in Moscow that he was planning to discuss the charges - widely seen as part of an attempt by internal security forces to restore their credibility after the Chechenia imbroglio - with other members of the Russian cabinet, in an effort to persuade them that they lacked any foundation.

The ISF was set up in 1992 to provide financial support for Russian scientists primarily through funds provided by the Hungarian-born financier George Soros. By the end of 1995, the foundation will have distributed $\$ 125$ million to about 50,000 scientists.

But earlier this month, the Nezavisimaya Gazeta ('Independent Newspaper'), published what it claimed to be excerpts from a report prepared by the federal counter-intelligence outlining how various US bodies were being used by US "special services" for carrying out "espionage and subversion on the territory of Russia".

The report pays particular attention to bodies such as the ISF, which have been collating information about the activities of Russian scientists as well as supporting collaborations with research teams in the West. "While publicly stating their aim as being to promote the development of Russian science, such bodies seek to conclude contracts with Russian scientists which result in exclu-

\section{Brazil keeps former minister in post}

São Paulo. Brazil's new president, Fernando Henrique Cardoso, who formally took office earlier this month, has decided to retain the former minister of science and technology, José Israel Vargas - a relatively unusual situation as new presidents usually change all government ministers.

Cardoso is a well-known sociologist and a former professor of the University of São Paulo, and Brazilian scientists are hoping that he will help them secure a reprieve from the hard times they have faced since the fall of the government of Fernando Collor de Mello in 1992.

Many are also optimistic about the retention of Vargas, who kept his position primarily because it is not considered a politically significant post. Vargas says he will continue to promote the technology needed to make Brazil's industries more competitive.

Under the administration of President
Itamar Franco, Vargas claims to have helped obtain funds for many university-based research groups. In particular, he claims credit for having rescued the Programme of Support for Scientific and Technological Development (PADCT), which operates through loans from the World Bank, and which had virtually disappeared by October 1992 because of the previous government's failure to provide the required matching funds.

But his claim is challenged by his predecessor, José Goldemberg, of the University of São Paulo. Goldemberg says that it was he who initiated the PADCT rescue, and that his period as science minister also saw the easing of tensions with the United States over science and technology issues including the replacement of the country's draconian laws barring the import of computers, which stultified research.

Ricardo Bonalume Neto sive rights being ceded to their discoveries and inventions," the report says. "By doing this, Americans effectively doom the Russian science and economy to lag behind."

The report points out that the ISF used questionnaires to obtain information from individuals and research centres, in return for which it offered them research grants. "The expert analysis of American question-

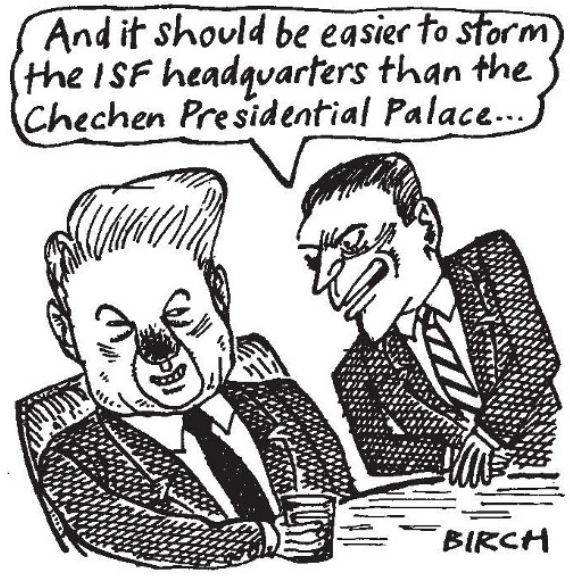

naires showed that the polls conducted by the US research centres provide them with an opportunity to receive much information about the person questioned, his relatives, their employment, their superiors and other data."

ISF officials deny that they are involved in espionage, claiming that, far from attempting to undermine the strength of Russian science, their only objective is to find ways of keeping it alive and helping it to thrive.

The report is being seen by some as a bid by conservative elements within the administration of President Boris Yeltsin to discredit reformist groups (such as the socalled YABLoko faction in Parliament) which often have close links with Westernfunded organizations.

But officials are still worried that, even if the report - dismissed as "naive" by the newspaper Pravda - cuts little ice with leading politicians and scientists, it could still have an adverse effect on administrators and researchers lower down the hierarchy, who may be reluctant to establish links with an organization held in suspicion by some parts of the Yeltsin administration.

Saltykov's intervention follows a personal request from Soros for an explanation of the status of the report.

Soros flew to Moscow last week to discuss the situation with Saltykov. At a press conference after their meeting, he said he welcomed Saltykov's assurances, and repeated his statement that the charges against the ISF were totally without foundation. 